\title{
Was Pasteur Wrong? Human Cells May Generate Bacteria
}

\author{
Alen J Salerian* \\ Modern Psychiatry, Athens, Greece
}

Received: May 22, 2018; Published: May 29, 2018

*Corresponding author: Alen Salerian, Modern Psychiatry, Athens, Greece

\section{Editorial}

Since 1856 when Louis Pasteur proved that infections originate from bacteria the germ theory has been the central paradigm in treating infectious disorders [1,2] (Figure 1). Of significance, the germ theory destined Antoine Bechamp, Pasteur's arch rivalto scientific obscurity while Pasteur became a legend of modern medicine. Today not many physicians even heard of Bechamp or his transformation theory: Body fluids -microsoma- may generate bac

teria and infections $[3,4]$. Surprisingly a novel hypotheses" Human body may produce bacteria "published in Medical Hypotheses [5] in June 2017 has not drawn any scientific attention despite offering compelling evidence to suggest that although Bechamp failed to offer experimental evidence to support" bacterial growth by transformation", he did indeed make a valid discovery that infections may originate by "pathways independent of contamination ".

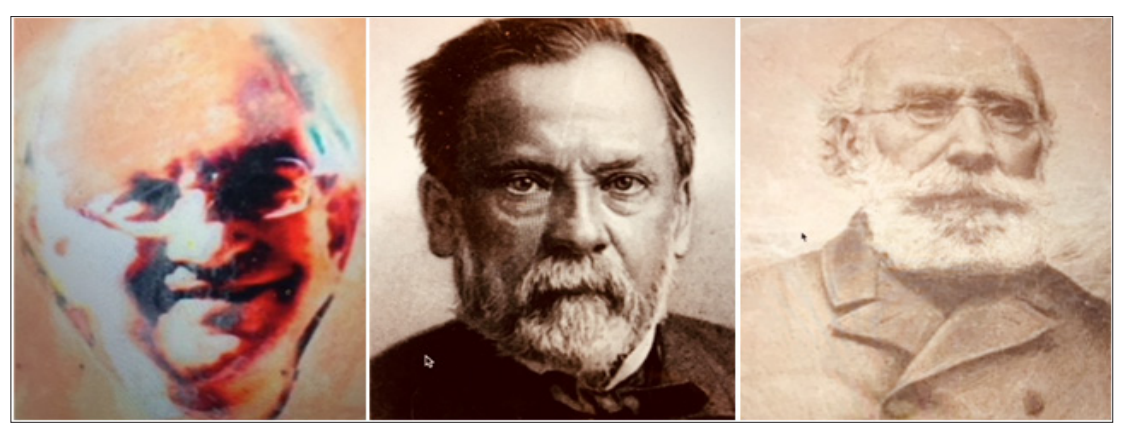

Figure 1: Alen Salerian, Pasteur, Bechamp.

History of science has been rich with observations that paradigm shifts have been difficult. For instance ptoleomic assumptions of the earth drop and being the center of universe lasted over thousand years before the Copernicus discovery. It is easy to prove Pasteur wrong for dismissing the existence of" pathways independent of contamination" to cause infections. This is because the first bacteria were born on lifeless earth not by contamination but transformation of nonliving things to bacteria [6]. Hence, that there are indeed pathways independent of contamination for bacterial growth.

Three observations prove that human cells are capable to transform to bacteria consistent with the following evidence:

a) Unicellular organisms transform to different unicellular organisms [7]. b) Human cells transform to different cells (cancer, stem cells to bone marrow) [8].

c) Human cells contain all the essentials for life.

Our current paradigm in treating infections -based upon the

premise that contamination is the only pathway for bacterial growth and infections-is flawed because of logical and physical impossibilities.

It is not logical because it has never been proven that that are no other pathways for bacterial growth. It is physically impossible because it violates the laws of evolution and history of life on earth. Burning infections reveal further evidence in support of transformation of dead or dying human cells to pathogens. Burning wound 
infections seem to be the rule rather than exception in major burns with the probability of infection at a rate of $96 \%$ in the first week [9]. This high rate of infections stands in contrast to burns routinely treated with anti-septic solutions and silver sulfadiazine. Also, heat induced tissue damage is equally lethal for microorganisms. Hence, the emergence of rare pathogens in burn infections seems consistent with transformation of dead or dying cells to virulent microorganisms.

In retrospect it seems that both Pasteur and Bechamp were partly wrong and partly correct and both contamination and transformation are valid pathways for bacterial growth and infections. This discovery may facilitate novel interventions to combat infections especially those associated with massive tissue losses, burns and major trauma. It may have other implications in medicine far beyond infectious disorders for it may lead to better understanding of various auto immune and inflammatory disorders, and relationship between environmental influences such as sudden temperature changes and common infections like cold or the flu. We may be prompted to investigate whether some infections result from transformation triggered by adverse environmental conditions-such as sudden temperature changes and especially exposure to cold-may lead to epidemics by host to host transmission.

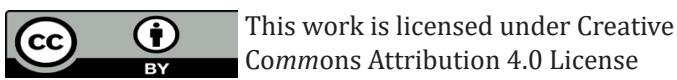

Submission Link: https://biomedres.us/submit-manuscript.php

\section{References}

1. Pasteur L (1880) On the extension of the germ theory to the etiology of certain common diseases.

2. Comptes Rendus de l'Academic des Sciences Xc Ernst (Ttrans). pp. 10331044.

3. Manchester KL, Louis Pastor (2007) fermentation and a rival. South African journal of science 103(9): 377-380.

4. Hume ED (1924) Bechamp or Pasteur? A lost chapter in the history of biology. Covici Mv Gee, Chicago.

5. BechampA, LesMicrozymas: Heterogeny, histogeny, physiology and pathology. Librarie JB Baillierre, Paris.

6. Salerian AJ (2017) Human body may produce bacteria. Medical Hypotheses 103: 131-132.

7. VanHolde KE (1980) the origins of life and evolution. Allan R Liss, New York, USA.

8. Krause DS, Thiese ND, Collector ML (2001) Multi-Organ, Multi-Lineage Engraftment by a Single Bone Marrow-Derived Stem Cell. Cell 105(3): 369-377.

9. Rosenow EC (1914) Test mutations within the streptococcus enamel proper school. Journal of Infectious Disorders 14(1): 1-32.

10. Macedo JLS Santos JB (2005) Bacterial and fungal colonization of burn wounds. Mem Inst Oswaldo Cruz 100(5): 535-539.

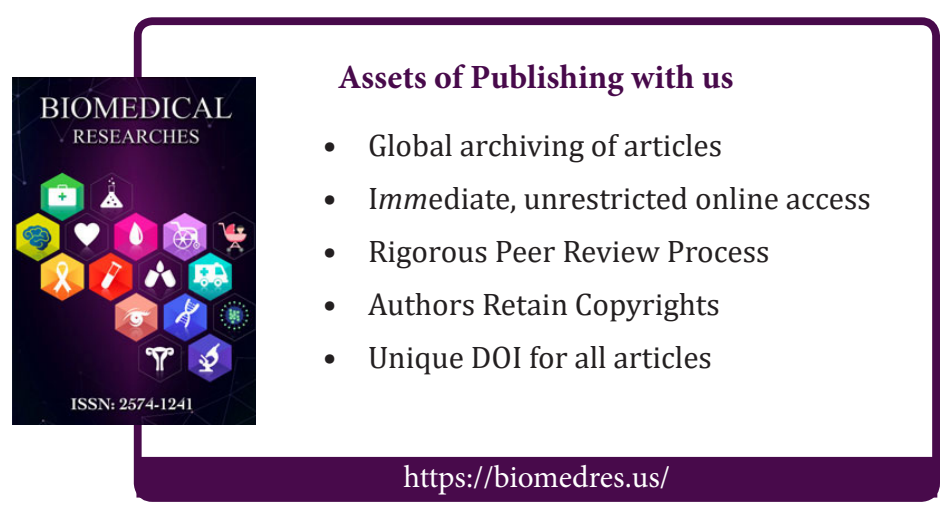

